payments or benefits to achieve the consent of a person having control over another person's, for the purpose of exploitation. Exploitation shall include, at a minimum, the exploitation of the prostitution of others or other forms of sexual exploitation, forced labour services, slavery or practices similar to slavery, servitude or the removal of organs;

b) The consent of a victim of trafficking in persons to the intended exploitation set forth in subparagraph (a) of this art. shall be irrelevant where any of the means set forth in subparagraph (a) have been used;

c) The recruitment, transportation, transfer, habrouring or receipt of a child for the purpose of exploitation shall be considered 'trafficking in persons' even if this does not involve any of the means set forth in sub paragraph (a) of the art.;

d) Child shall mean any person under eighteen years of age.

Trafficking violates a child's right to grow up in a family environment and exposes him or her to a range of dangers, including violence and sexual abuse. In India over the last decade, the volume of human trafficking has increased though the exact numbers are not known, it is one of the most lucrative criminal trades, next to arms and drug smuggling undertaken by highly organized criminals.

\section{CHILD TRAFFICKING}

The movement or exchange of youngsters is portrayed by the enrolment, transport, exchange, and lodging of any individual by various strategies. It might likewise include falling back on drive or some other types of restriction, through capturing, misdirection, extortion, and also the manhandle of expert. Offering, tolerating instalments, or advantages for getting the assent of the casualty (or individual having specialist over the casualty) are additionally illegal acts that add to kid trafficking.

Child trafficking has no general definition, however numerous lawful instruments specify it. One of these is the Convention on the Rights of the Child of 1989, which alludes to youngster trafficking in Article 11 line 1, stipulating that "unlawful exchange and nonreturn of kids" is illegal.

Traffickers arrange themselves by means of huge universal systems, which take part in numerous exercises, for example, sedate trafficking or prostitution.

Molded to obey through physical and mental savagery, youngsters are frequently kept in outside spots. Semantic and geographic disconnection reinforces the hold that traffickers have on their casualties who can't get away.

\section{CAUSES OF CHILD TRAFFICKING}

The problem of child trafficking is the result of a constellation of factors, including widespread poverty, lack of livelihood opportunities, entrenched gender discrimination, displacement, the demand for young girls, the upheaval associated with natural disasters/conflict in parts of the country and the profits to be made. In some cases, socio-cultural and religious factors have an impact on child trafficking, as where religious figures have made use of their position to traffic girls for prostitution. Additional risk factors include, for example, parent illiteracy, illness or death of one of the main family breadwinners, unemployment, early school drop-out of the concerned children, absence of workplace inspection or policing, and a specific demand for child labour. Frequently, trafficking is accomplished through the deception of girls and their families. In many villages in West Bengal it is reported that traffickers have obtained access to girls by pretending to be grooms without dowry demands. In other cases, trafficking has been facilitated by relatives or friends of the victims, as well as teachers and placement agencies. The traffickers also exploit lack of political will by governments to tackle trafficking and its root causes. Moreover, girls who have been exploited are also commonly used to lure girls from source areas.

Also, increasing breakdown of social structures (which results in a loss of family and community support networks, making families, particularly women and children, increasingly vulnerable to traffickers demands and threats); Globalization and economic disparities between countries, and porous borders facilitates easy movement of people and large-scale illegal migration of women and children into India from the neighboring countries and this illegal migration are exploited by the traffickers to traffic women and children into exploitative situations, including prostitution and labour

Children are sold for the purposes of sexual exploitation, begging, soliciting, or for forced 
marriages. They risk themselves in construction work, working in factories, or are employed as domestic servants. Children are given for a substantial sum of money to parents waiting to adopt.

The sale of child organs is more and more frequent. To escape their living conditions, some children are ready to sell one of their kidneys for money. The sale of organs represents between $5 \%$ and $10 \%$ of kidney transplants performed in the world each year.

\section{WHAT ARE CHILDREN TRAFFICKED FOR?}

\section{Labour}

- Bonded labour

- Domestic work

- Agricultural labour

- Construction work

- Carpet industry, garment industry, fish / shrimp export as well as other sites of work in the formal and informal economy.

Illegal Activities

- Begging

- Organ trade

- Drug peddling smuggling

Sexual Exploitation

- Forced prostitution

- Socially and religiously sanctified forms of prostitutions

- Sex tourism

- Pornography

Entertainment and Sports

- Circus, dance troupes, beer bars etc.

- Camel jockeys

- For and through marriage

- For and through adoption

- As child soldiers or combatants in armed conflicts

\section{THE PROBLEM OF CHILD TRAFFICKING IN INDIA}

Despite the fact that usually hard to get far reaching information on the degree of human trafficking in
India, it is by and large acknowledged that India is a source, goal, and travel nation for trafficking of people, including young ladies. A recent report found that 378 of the 593 regions were influenced by human trafficking. It is assessed that $90 \%$ of trafficking in the nation is interior, with casualties of trafficking for the most part being utilized for constrained work. Tyke casualties of trafficking in India are abused from numerous points of view - including production line and agrarian laborers, household workers and hobos. Young ladies, specifically, are helpless against trafficking with the end goal of constrained marriage and business sexual abuse.

The permeable fringes in the area are frequently referred to as a contributing component to crossoutskirt trafficking, including the trafficking of young ladies from Nepal and Bangladesh to India. ECPAT International gauges that 150,000 ladies and kids are trafficked from South Asia every year, most from, through or to India. The joined assessments for Nepal and Bangladesh extend from 500 to 10,000 young ladies being trafficked to India every year; another gauge puts the figure at more than 200,000 over a time of seven years. At show, there are no laws representing the repatriation of trafficking casualties from India to Bangladesh and Nepal and concerned associations have looked to help young ladies in achieving their homes by liaising with accomplice associations in these nations.

\section{ROLE OF DIFFERENT SECTORS}

\section{Role of NGOs}

- The community should be sensitized about trafficking the community members should be motivated to keep a watch in the community for irregular movement of child victims to and from area their possible traffickers and hideouts.

- NGOs must also give awareness to the people regarding the rights available against trafficking as well as child trafficking is inappropriate and illegal and has negative consequences also.

- NGOs working in the rural areas should ensure that parents are aware of safe migration practices.

- Victims can be made aware of places and institutions where they can seek help. 


\section{Role of State}

- Government at local level and source areas should create compulsory high quality education.

- Government should produce relevant IEC (The International Electro technical Commission) materials; promote sensitization programmes for teachers in government schools, parents and community workers.

- Government should include gender cantered education system in schools and introduce subjects of child sexual abuse and trafficking.

- Government must also focus on providing equal employment opportunities and income generation programme.

- The government of different nations must share the information with each other to evolve a programme that will help both the countries in preventing trafficking.

\section{IN THE CASE OF PEOPLE'S UNION FOR DEMOCRATIC RIGHTS V. UNION OF INDIA. ${ }^{2}$}

The scope and ambit of art. 23 is been considered by Supreme Court in detail. It was held that the scope of art. 23 is very wide and unlimited and strikes at "traffic in human beings" and "beggar" and other forms of forced labour wherever they are found. Thus, this art. focuses at forced labour in whatever form it may manifest itself because it is violative of human dignity and contrary to basic human values .Here the word "force" was construed widely as to include not only physical or legal force but also force arising out of compulsion of economic circumstances.

Art. 39- Certain policies to be followed by the state This art specifically requires the state to ensure adequate means of livelihood to its people, fair distribution of wealth, equal pay for equal work and protection of children and labour from trafficking. The makers of the Constitution did not desire that there should be a society where a citizen's will not have the dignity of the individual ${ }^{3}$

\section{CONCLUSION}

Tending to human trafficking genuinely requires a far reaching and multi-faceted methodology, which incorporates endeavors went for the restoration and social reintegration of trafficked casualties. Something else, the procedure won't be effective over the long haul. Basically, at the simple center of any hostile to trafficking methodology must be an enduring duty from singular nations and other multilateral on-screen characters to address human trafficking at each phase of this cycle, from aversion to enlistment, transportation to fortified work, and from save to reintegration. Without this dedication, against trafficking endeavors will be in a general sense unfit to mediate for the benefit of the trafficked casualties whose human rights infringement shape the foundation of this exploitative exchange.

Additionally, the sanctioning of the law on paper with no genuine preparing and support to the functionaries would be worthless and in this way, what is required currently is "real", "arranged" and "compelling" execution. Including the network investment in the entire execution process would make a more noteworthy effect. The strategies and details ought not lessen the yearning enactments to purge words, on the grounds that in question here is the kids the eventual fate of the country. Child or human trafficking can't be completely destroyed, however by taking some proper measures it can be counteracted on an awesome degree. In doing as such our Indian law and government has made different strides expressed above to forestall trafficking. The guilty party must be rebuffed with serious discipline so a similar demonstration can't be rehashed.

After a legitimate investigation of every last part of human trafficking, the conclusion is that the dangers required for a trafficker should be developed through different provisions of laws. In India particularly, one needs to guarantee the level of collaboration between the victims of trafficking and law officers ought to be expanded to convey such low-less creatures to equity. Comprehensively further advances ought to be taken to guarantee that mindfulness is spread. The global participation at the level of police and at a legal level ought to be increased. International cooperation additionally requires practice bureaus of activity control.

\footnotetext{
${ }^{2}$ AIR 1982 SC 1943
} 